\title{
Changes in hepatitis B virus DNA polymerase in relation to the outcome of acute hepatitis type $B$
}

\author{
A. Alberti, S. DiAnA, A. L. W. F. EDdLeSton, AND ROGER Williams \\ From the Liver Unit, King's College Hospital and Medical School, Denmark Hill, London
}

SUMMARY Serum levels of hepatitis B virus specific DNA polymerase and hepatitis B e antigen were studied serially in 34 patients with hepatitis B virus infection-20 who had the acute illness and recovered, seven who died with fulminant disease, three who died as a result of subacute hepatic necrosis, and four who went on to develop chronic active hepatitis. DNA polymerase activity was present in $16(80 \%)$ and $\mathrm{HBeAg}$ in $13(65 \%)$ of the uncomplicated cases at presentation and in all of those patients from whom the initial sample was obtained before the peak in aminotransferase. Both markers disappeared after 30 days from the onset but DNAP remained persistently positive during a follow-up period of four to 10 months in the four patients who progressed to chronic hepatitis. These results indicate that DNAP and $\mathrm{HBeAg}$ are transiently present in all cases of acute hepatitis B. Only their persistence after the acute episode could represent a useful prognostic marker of chronicity. In this respect, DNAP was more reliable in our patients than $\mathrm{HBeAg}$. In uncomplicated acute hepatitis, the peak in DNAP levels, which defines the time of maximum virus replication in the liver, preceded the peak in aminotransferase levels. Among the 10 patients who developed massive liver damage after hepatitis B infection, DNAP was detected in five of the seven with fulminant hepatitis, with enzyme levels that were comparable with those observed in uncomplicated acute hepatitis at presentation, but not in the cases of subacute hepatic necrosis. These findings are consistent with the hypothesis that in hepatitis B infection, liver damage, whatever the severity, is not directly related to the degree of virus replication.

Dane particles, considered to represent the complete form of the hepatitis B virus (HBV), have an inner core that contains endogenous DNA polymerase (DNAP) which utilises as template circular viral DNA (Lutwick and Robinson, 1977). These have been termed full particles to distinguish them from those particles which may also be found in $\mathrm{HBsAg}$ positive sera but lack complete viral DNA within their cores and are DNAP negative (empty Dane particles) (Kaplan et al., 1976). HBV specific DNAP activity can be detected in the serum of some patients chronically infected with HBV and represents a marker of active replication of the complete virus (Kaplan et al., 1973). Its presence is often independent of the severity of the associated liver disease (Tong $e t$ al., 1977; Alberti et al., 1978), the highest levels usually being found in immunosuppressed patients (Nordenfelt and Kjellén, 1975) and in some series

Received for publication 19 September 1978 presence of enzyme activity in serum has been shown to correlate with the detection of $\mathrm{HBeAg}$ in the serum (Nordenfelt and Kjellén, 1975; Hindman et al., 1976) and with the finding of circulating full Dane particles on electron microscopy (Alberti et al., 1978).

Transient detection of HBV specific DNAP in patients with acute hepatitis B was first reported by Kaplan et al. (1974) in cases of post-transfusional hepatitis and by Krugman et al. (1974) in five selected patients who developed acute hepatitis after parenteral, contact or oral exposure to HBV. However, serial determinations of DNAP activity in a significant number of cases of acute hepatitis $B$ have not been reported and the relation of $\mathrm{HBV}$ replication to the clinical course and outcome of the disease has also not been determined. This was our aim in the present study of 34 cases of varying severity and at different stages of the disease. In addition to serial estimations of DNAP, we have examined its relationship to $\mathrm{HBeAg}$ and, in selected cases, to circulating complete and defective forms of $\mathrm{HBV}$, as represented by full and empty Dane particles. 


\section{Methods}

\section{PATIENTS}

Three groups of patients were studied.

1. Serum samples were obtained from 20 cases of acute hepatitis B within three days after the onset of symptoms and at weekly intervals during the acute phase of illness. In all cases liver function tests returned to normal values within two months from the onset.

2. This group contained seven patients with fulminant heparitis who had progressed to grade III or IV coma within three to six days after the onset of symptoms, and three patients who died of subacute hepatic necrosis four to eight weeks after the onset of symptoms. In these 10 cases serum samples were obtained within 24 hours after the development of coma.

3. The final group consisted of four patients who remained $\mathrm{HBsAg}$ positive six to 10 months after acute hepatitis B. At this time liver function tests were abnormal in all four and in three of them, in whom liver biopsy was carried out, progression to chronic active hepatitis was observed. In these patients serial serum samples were obtained during a follow-up period of four to 10 months. $\mathrm{HBsAg}$ was tested by radioimmunoassay (Ausria II, Abbott) and titred by passive haemagglutination (Hepatest, Wellcome). $\mathrm{HBeAg}$ and anti-HBe were investigated by immunodiffusion.

DNAP ACTIVITY AND ELECTRON MICROSCOPY HBV specific DNAP activity was measured in 20 fold concentrated pellets prepared from sera by ultracentrifugation (Kaplan et al., 1973). The upper limit of background activity ( $250{ }^{3} \mathrm{H}-\mathrm{TTP} \mathrm{cpm}$ ) was defined using pellets prepared from $\mathrm{HBs} A \mathrm{Ag}$-negative control sera and the specificity of the enzyme activity was assessed by immunoprecipitation with anti-HBs (Alberti et al., 1978). Presence of circulating Dane particles and the proportion of full and empty forms were estimated by electron microscopy (EM) on serum pellets prepared by ultracentrifugation using negative (3\% phosphotungstic acid $\mathrm{pH} 6.0)$ and positive $(0.2 \%$ uranyl acetate $\mathrm{pH} 5.0)$ stainings (Alberti et al., 1978).

\section{Results}

Sixteen $(80 \%)$ of the 20 patients with acute hepatitis B were found to be DNAP positive when tested within three days after the onset of symptoms. In 13 of these 16 patients, $\mathrm{HBeAg}$ was also detectable in the same serum sample. The number of cases with positive sera fell progressively during the illness and in no case were either of the viral markers detectable after 30 days (Fig. 1). DNAP activity levels were significantly higher in the presence than in the absence of $\mathrm{HBeAg}$, even when corrected for the time after onset with levels of $634.9 \pm 170 \mathrm{cpm}$ and $264 \pm 83$ cpm $(\mathrm{P}<0.001)$ for HBeAg positive and $\mathrm{HBeAg}$ negative sera respectively at one to 10 days of illness, and $436 \pm 59 \mathrm{cpm}$ and $196 \pm 63 \mathrm{cpm}(\mathrm{P}<0.001)$ for $\mathrm{HBeAg}$ positive and negative sera at 10 to 20 days of illness.

Dane particles were seen by EM in sera of $17(85 \%)$ cases at presentation, in $13(65 \%)$ after 10 days, and had become undetectable in all cases after 30 days. Although the largest numbers of particles were found in sera positive for $\mathrm{HBeAg}$ and DNAP, Dane

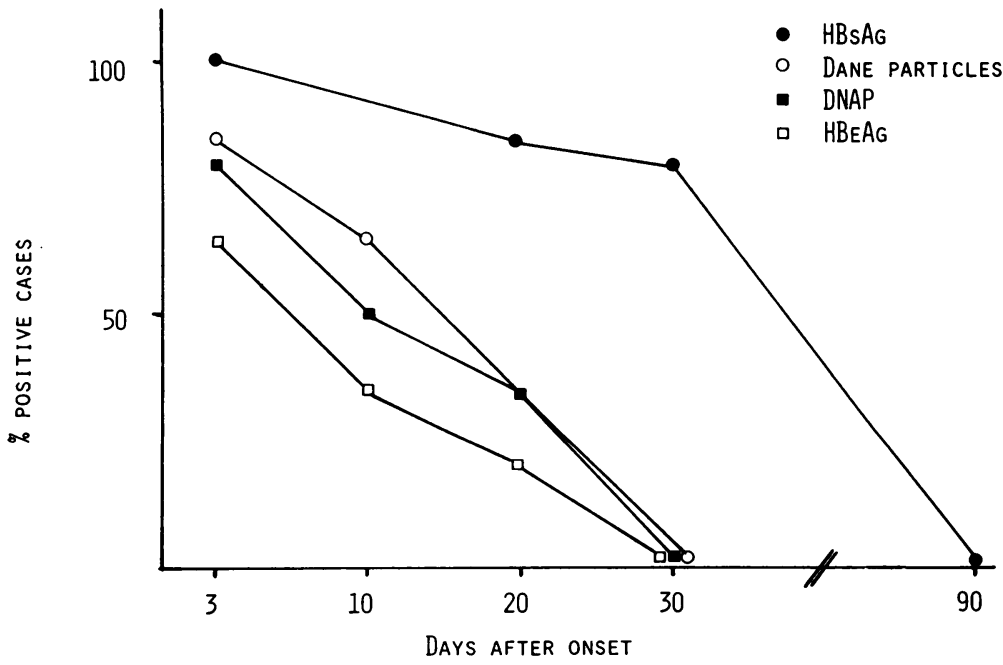

Fig 1 Hepatitis $B$ virus markers in 20 uncomplicated cases of acute hepatitis $B$. 
particles were also seen in sera negative for $\mathrm{HBeAg}$ and DNAP, particularly at the time of high serum aminotransferase levels.

In all eight cases where the initial serum sample was obtained before the peak in serum aminotransferase values, $\mathrm{HBeAg}$ and DNAP activity were detected (Fig. 2). The highest levels of DNAP activity always preceded the aminotransferase peak and by this time enzyme activity had fallen considerably in seven cases and had become undetectable in one. However, circulating Dane particles were still detectable by EM. In three of these cases Dane particle pellets prepared at the time of DNAP peak and at the time of the aminotransferase peak were stained with uranyl acetate. The percentage of full particles varied between 16 and $29 \%$ within the first group and between 1 and $5 \%$ in the second.

In contrast with $\mathrm{HBeAg}, \mathrm{HBsAg}$ was still detectable by passive haemagglutination in $80 \%$ of cases after 30 days, and did not become negative by RIA until three months from the onset.

\section{FULMINANT HEPATITIS AND SUBACUTE HEPATIC NECROSIS}

DNAP activity was detected in five $(71 \%)$ of the seven cases with fulminant hepatitis. This frequency, as well as DNAP levels, were comparable with that obtained in the cases of uncomplicated acute hepatitis B at presentation, although HBsAg titres were significantly lower (Table). In contrast, DNAP activity was not detected in the three cases of subacute hepatic necrosis while $\mathrm{HBs} A g$ titres in these patients were similar to those found in fulminant hepatitis (Table). Furthermore, circulating Dane particles were seen by EM in the serum of fulminant hepatitis cases but not in those with subacute hepatic necrosis.

Two patients (cases 1 and 4) with fulminant hepatitis were retested three and nine days after the initial samples. In both, DNAP and Dane particles had become undetectable and $\mathrm{HBsAg}$ remained positive by RIA in only one of them.

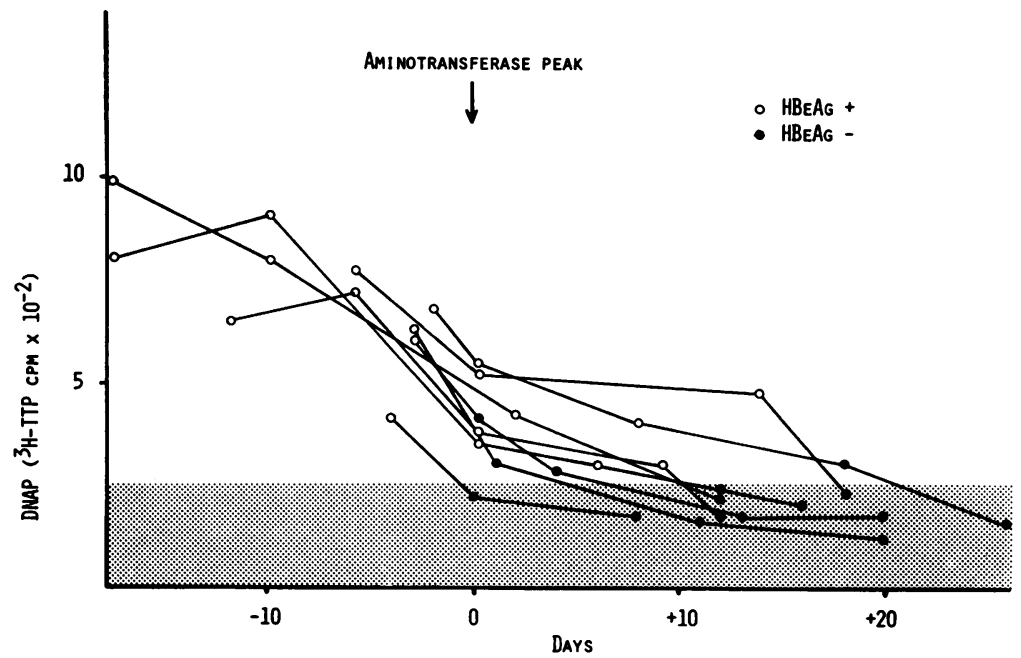

Fig. 2 Changes in $H B V-D N A$ polymerase and $\mathrm{HBe} A \mathrm{~g}$ in acute hepatitis $B$ in relation to the aminotransferase peak. Shaded area represents normal range.

Table Hepatitis B virus markers in fulminant hepatitis and in subacute hepatic necrosis after hepatitis $B$ infection

\begin{tabular}{|c|c|c|c|c|c|c|}
\hline Case & $\begin{array}{l}\text { Days after } \\
\text { onset }\end{array}$ & $\begin{array}{l}\text { HBs Ag } \\
(P H A \text { titre })\end{array}$ & $\mathrm{HBeAg}$ & $A n t i-H B e$ & $\begin{array}{l}D N A P \\
\left({ }^{3} H-T T P \text { cpm }\right)\end{array}$ & $\begin{array}{l}\text { Dane particles } \\
(E M)\end{array}$ \\
\hline \multicolumn{7}{|c|}{ Fulminant hepatitis } \\
\hline 1 & 6 & $1: 1600$ & Negative & Negative & 368 & Positive \\
\hline 2 & 3 & $1: 256$ & Negative & Negative & 343 & Not tested \\
\hline 3 & 3 & $1: 400$ & Positive & Negative & 671 & Positive \\
\hline 4 & 3 & $1: 256$ & Negative & Negative & 881 & Positive \\
\hline 5 & 6 & RIA* & Negative & Negative & $139+$ & Not tested \\
\hline 7 & 6 & $1: 128$ & Negative & Negative & $212 \dagger$ & Not tested \\
\hline \multicolumn{7}{|c|}{ Subacute hepatic necrosis } \\
\hline 1 & 45 & $1: 1600$ & Negative & Positive & $144 \dagger$ & Negative \\
\hline 2 & 53 & $1: 256$ & Negative & Negative & $163 t$ & Negative \\
\hline 3 & 30 & $1: 512$ & Negative & Negative & $179+$ & Negative \\
\hline
\end{tabular}

* Negative by PHA but positive by RIA.

†Values within the normal range. 
PATIENTS WITH PERSISTENCE OF HBSAg IN SERUM

In these four cases, DNAP was persistently detected (Fig. 3). HBeAg was present persistently in one patient and transiently in another, in whom it disappeared 95 days after the onset of the acute episode. Dane particles, including 10 to $32 \%$ of full particles, were persistently present in the serum of these patients.

\section{Discussion}

Our results show that detection of $\mathrm{HBV}$ specific DNAP and HBeAg in acute hepatitis B is clearly dependent on the timing of the initial serum sample. Overall, $65 \%$ and $80 \%$ of cases were found to be positive for $\mathrm{HBeAg}$ and DNAP respectively at presentation, both markers being present in every case in whom the initial serum sample was obtained before the aminotransferase peak. It therefore seems reasonable to assume that these specific markers of HBV are transiently present in all patients with acute hepatitis due to a type $B$ infection, and that their detection during the acute phase cannot be considered of prognostic value, as proposed in earlier studies (Nielsen et al., 1974; Norkrans et al., 1976). Levels of DNAP activity were high before the peak in aminotransferase levels and had already fallen at the time of maximum liver damage. These findings suggest that virus replication and release of complete virus particles from infected hepatocytes occur indepen- dently of the liver damage. However, appearance of viral antigens at the hepatocyte surface during virus replication and release could induce the host immune response against the altered cell membrane, leading to destruction of infected cells. Indeed, $\mathrm{HBsAg}$ has been demonstrated at the hepatocyte surface in this phase of the disease both in susceptible animals (Barker et al., 1973) and in patients (Alberti et al., 1976).

Although Dane particles were still detectable in serum at the time of aminotransferase peak even in those cases where DNAP activity had become low or absent, most of these particles appeared to be of the incomplete or empty variety. Whether the increase in the proportion of these particles, presumably as a result of defective viruses from damaged liver cells, is related to the termination of virus replication, as suggested by Kaplan et al. (1976), remains to be clarified. Defective virus particles are known to interfere with the intracellular replication of complete viruses (Huang, 1970).

The failure to show correlation between $\mathrm{HBeAg}$ and DNAP activity in acute hepatitis $B$ recently reported by Cappel et al. (1977) could have been related to an earlier disappearance of $\mathrm{HBeAg}$ compared with DNAP activity, as we also observed, although this is more likely to be a consequence of the difference in the sensitivity of the methods of detection rather than a true biological phenomenon. Indeed, in our cases DNAP activity was always present in sera positive for $\mathrm{HBeAg}$. Enzyme activity

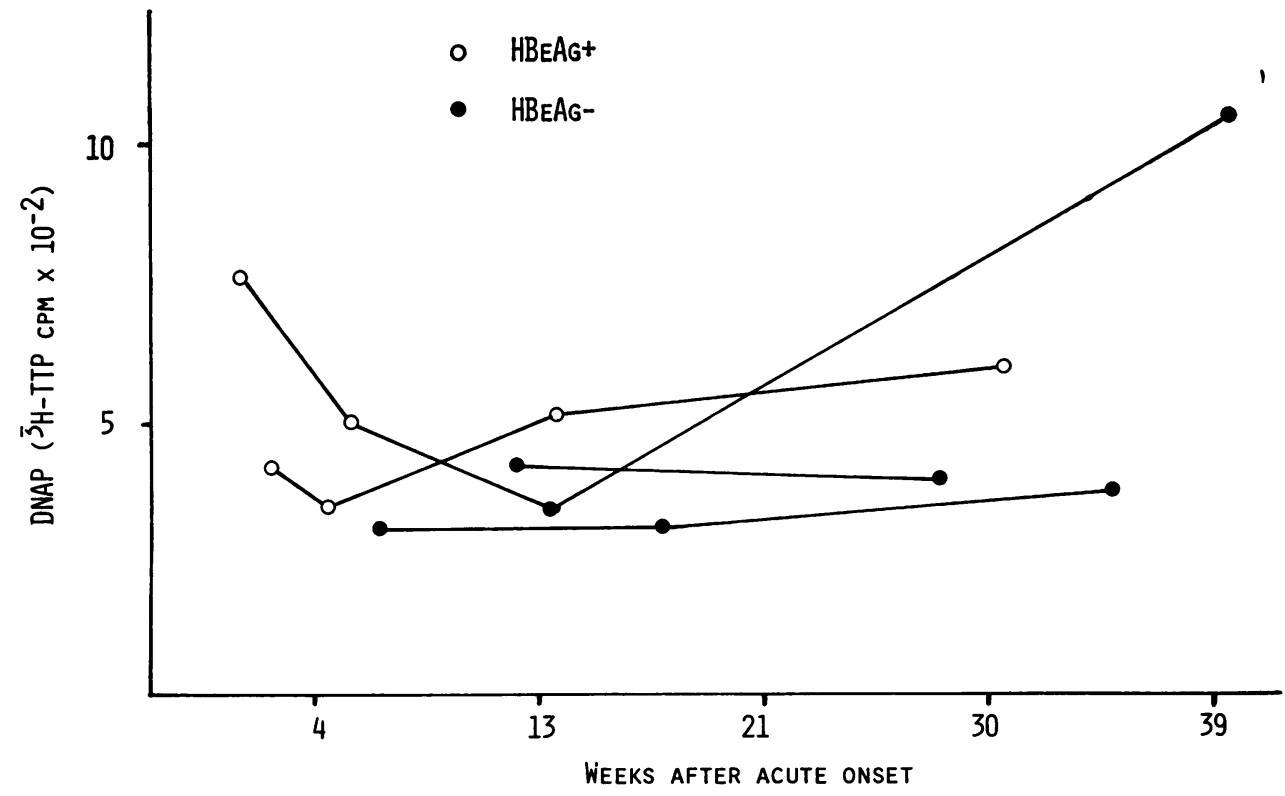

Fig. 3 Changes in $\mathrm{HBV}$-DNA polymerase and $\mathrm{HBeAg}$ in four patients showing progression to chronic liver disease after acute hepatitis $B$. 
was also detected in cases who had already become $\mathrm{HBeAg}$ negative but in these sera mean values were significantly lower. The association of $\mathrm{HBeAg}$ with DNAP activity in acute hepatitis type B confirms previous findings in chronic carriers of $\mathrm{HBsAg}$ and provides further evidence that $\mathrm{HBeAg}$ is a marker of active replication of the complete $\mathrm{HBV}$ rather than of liver damage.

Both Vogten et al. (1976) and Neurath and Strick (1977) suggested that $\mathrm{HBeAg}$ could be a marker of an impaired immune response to the $\mathrm{HBV}$, in particular of a defect in the host mechanisms involved in virus clearance. Our results do not support this hypothesis, as, in all cases, DNAP activity became undetectable within 20 to 30 days after the onset of illness, including those cases who had $\mathrm{HBeAg}$ in serum.

DNAP levels in fulminant hepatitis at the time of development of coma were comparable with those observed in the early phase of uncomplicated acute hepatitis B. The differences in the clinical course are unlikely to be a consequence of the degree of virus replication. The striking differences in $\mathrm{HBs} A g$ titres observed between the two groups is consistent with the suggestion that there is an enhanced humoral immune response to $\mathrm{HBsAg}$ in fulminant hepatitis (Woolf et al., 1976). Indeed, the detection of DNAP activity in the presence of low $\mathrm{HBsAg}$ titres supports the hypothesis that in these patients large complexes of viral particles, including complete virions, are present in the circulation. However, the present evidence is not sufficient completely to exclude the possibility that there may be diminished production of $\mathrm{HBsAg}$ in fulminant hepatitis. DNAP activity was not detected at the time of development of coma in the cases who followed the more chronic, but equally fatal, course of subacute hepatic necrosis. The pathogenesis of this condition remains obscure, and our results suggest that in these cases, although DNAP activity was probably present at an earlier stage, at the time of massive liver damage replication of HBV was not enhanced.

In those patients who progressed to $\mathrm{HBsAg}$ positive chronic liver disease HBV-DNAP remained persistently positive, while in those who recovered it disappeared from the serum within 30 days after the onset, suggesting that this could represent an early prognostic marker of chronicity. In this respect, DNAP was more useful in our cases than $\mathrm{HBeAg}$, although this may simply be a reflection of the sensitivity of the presently available methods of detection. The observation that in these cases DNAP activity and full Dane particles are persistently present in sera after the acute episode indicates that this chronic evolution is associated, at least within the first four to 10 months after the acute episode, with a high degree of virus replication in the liver, possibly as a consequence of continuing reinfection of liver cells related to a defect in the mechanisms of virus neutralisation (Eddleston and Williams, 1974). However, in the later stages of the illness replication of the complete HBV may be partially suppressed, as DNAP activity and full Dane particles are rarely detected in the serum of patients with HBsAg postive chronic active hepatitis who have progressed to cirrhosis (Alberti et al., 1978).

We are grateful to Miss Helen Cullens and Professor A. J. Zuckerman for HBsAg testing, to Dr J. Vahrman and Dr G. Realdi for their help with some of the patients in this study, and to Linda Rimmer for editorial assistance. The Wellcome Trust provided financial support, and Dr Alberti was supported by an Annavilla Rusconi Fellowship.

\section{References}

Alberti, A., Realdi, G., Tremolada, F., and Spina, G. P. (1976). Liver cell surface localisation of hepatitis B antigen and of immunoglobulins in acute and chronic hepatitis and in liver cirrhosis. Clinical and Experimental Immunology, 25, 396-402.

Alberti, A., Diana, S., Scullard, G. H., Eddleston, A. L. W. F., and Williams, R. (1978). Full and empty Dane particles in chronic hepatitis B virus infection: relation to hepatitis B e antigen and presence of liver damage. Gastroenterology, 75, 869-874.

Barker, L. F., Chisari, F. V., McGrath, P. P., Dalgard, D. W., Kirschstein, R. L., Almeida, J. D., Edgington, T. S., Sharp, D. G., and Peterson, M. R. (1973). Transmission of type B viral hepatitis to chimpanzees. Journal of Infectious Diseases, 127, 648-662.

Cappel, R., De Cuyper, F., and Van Beers, D. (1977). E antigen and antibody, DNA polymerase, and inhibitors of DNA polymerase in acute and chronic hepatitis. Journal of Infectious Diseases, 136, 617-622.

Eddleston, A. L. W. F., and Williams R. (1974). Inadequate antibody response to $\mathrm{HBAg}$ or suppressor T-cell defect in development of active chronic hepatitis. Lancet, 2, 15431545

Hindman, S. H., Gravelle, C. R., Murphy, B. L., Bradley, D. W., Budge, W. R., and Maynard, J. E. (1976). "E"' antigen, Dane particles, and serum DNA polymerase activity in HBsAg carriers. Annals of Internal Medicine, 85, 458-460.

Huang, A. S. (1970). Defective interfering viruses. Annual Review of Microbiology, 27, 101-117.

Kaplan, P. M., Ford, E. C., Purcell, R. H., and Gerin, J. L. (1976). Demonstration of sub-populations of Dane particles. Journal of Virology, 17, 885-893.

Kaplan, P. M., Gerin, J. L., and Alter, H. J. (1974). Hepatitis B-specific DNA polymerase activity during post-transfusion hepatitis. Nature, 249, 762-763.

Kaplan, P. M., Greenman, R. L., Gerin, J. L., Purcell, R. H., and Robinson, W. S. (1973). DNA polymerase associated with human heptitis B antigen. Journal of Virology, 12, 9951005.

Krugman, S., Hoofnagle, J. H., Gerety, R. J. Kaplan, P. M., and Gerin, J. L. (1974). Viral hepatitis, type B: DNA polymerase activity and antibody to hepatitis B core antigen. New England Journal of Medicine, 290, 1331-1335. 
Lutwick, L. I., and Robinson, W. S. (1977). DNA synthesized in the hepatitis B Dane particle DNA polymerase reaction. Journal of Viology, 21, 96-104.

Neurath, A. R., and Strick, N. (1977). Host specificity of a serum marker for hepatitis B: evidence that "e antigen" has the properties of an immunoglobulin. Proceedings of the National Academy of Science (USA), 74, 1702-1706.

Nielsen, J. O., Dietrichson, O., and Juhl, E. (1974). Incidence and meaning of the " $e$ " determinant among hepatitis-Bantigen positive patients with acute and chronic liver diseases. Lancet, 2, 913-915.

Nordenfelt, E., and Kjellén, L. (1975). Dane particles, DNA polymerase and e-antigen in two different categories of hepatitis B antigen carriers. Intervirology, 5, 223-232

Norkrans, G., Magnius, L., and Iwarson, S. (1976). E antigen in acute hepatitis B. British Medical Journal, 1, 740-742.

Tong, M. J., Stevenson, D., and Gordon, I. (1977). Correlation of e antigen, DNA polymerase activity, and Dane particles in chronic benign and chronic active type $B$ hepatitis infections. Journal of Infectious Diseases, 135, 980-984.

Vogten, A. J. M., Schalm, S. W., Summerskill, W. H. J., Smith, J. L., Gitnick, G. L., Murphy, B. L., and Maynard, J. E. (1976). Behaviour of e antigen and antibody during chronic active liver disease: relation to $\mathrm{HB}$ antigenantibody system and prognosis. Lancet, 2, 126-128.

Woolf, I. L., El Sheikh, N., Cullens, H., Lee, W. M., Eddleston, A. L. W. F., Williams, R., and Zuckerman, A. J. (1976). Enhanced HBsAb production in pathogenesis of fulminant viral hepatitis type B. British Medical Journal, 2, 669-671. 